\begin{tabular}{|c|l|}
\hline Title & Factors affecting arsenic mobility from hydrothermally altered rock in impoundment-type in situ experiments \\
\hline Author(s) & Tabelin, Carlito B.; Igarashi, Toshifumi; Tamoto, Shuichi \\
\hline Citation & $\begin{array}{l}\text { Minerals Engineering, 23(3), 238-248 } \\
\text { https:/doi.org/10.1016/.mineng.2009.09.019 }\end{array}$ \\
\hline Issue Date & 2010-02 \\
\hline Doc URL & http://hdl.handle.net/2115/47800 \\
\hline Type & article(author version) \\
\hline File Information & ME23_3_238_248.pdf \\
\hline
\end{tabular}

Instructions for use 


\title{
Factors affecting arsenic mobility from hydrothermally altered rock in impoundment-type in-situ experiments
}

\author{
Carlito B. Tabelin* ${ }^{1}$, Toshifumi Igarashi ${ }^{1}$ and Shuichi Tamoto ${ }^{2}$ \\ ${ }^{1}$ Division of Field Engineering for Environment, Graduate School of Engineering, Hokkaido University, Sapporo \\ 060-8628, JAPAN \\ ${ }^{2}$ Civil Engineering Research Institute for Cold Region, Public Works Research Institute, Sapporo 062-8608, JAPAN \\ E-mails: carlito@trans-er.eng.hokudai.ac.jp, tosifumi@eng.hokudai.ac.jp and 95353@ceri.go.jp
}

\begin{abstract}
This paper describes the factors affecting arsenic (As) mobility from hydrothermally altered rock under in-situ conditions. Four impoundments were built on site with rectangular base, truncated-pyramid structures. Impoundment 1 was composed solely of the hydrothermally altered rock while impoundments 2, 3 and 4 were covered with different types of silty covering soil in order to minimize $\mathrm{O}_{2}$ and water intrusion into the rock. The results indicate that seasonal variations in temperature, $\mathrm{O}_{2}$ concentration and volumetric water content in the impoundments strongly influenced As leaching. When the temperature was high and the water content low, oxidation of sulfide minerals in the rock was enhanced because of a higher air-water-rock interaction. Concentration of As in the porewater increased when it rained after a specific period of dry weather. The use of a silty covering soil influenced the concentrations of As and $\mathrm{SO}_{4}^{2-}$ in the porewater although it did not affect the $\mathrm{pH}$ and Eh significantly. In this case, $\mathrm{O}_{2}$ and water movement might be the rate controlling step of As leaching, that is, if there is no covering soil on the impoundment, more As will leach out from the rock. The use of a silty covering soil showed promise of reducing As leaching from the waste rock, but utilizing it alone was insufficient to effectively prevent As release from the rock. A combination of covering soil and bottom As-adsorption layer to incorporate any As released from the rock is therefore recommended.
\end{abstract}

Keywords: Leaching; oxidation; redox reactions 


\section{INTRODUCTION}

Arsenic (As) is a metalloid, an element with both metallic and non metallic properties, that is present in rocks, soil, salt and fresh water bodies, volcanic emissions, biological activities and even in the atmosphere making it ubiquitous in nature. It is a major constituent in more than 200 minerals, including elemental As, arsenides, sulfides, oxides, arsenates and arsenites, and is concentrated in mineralized areas usually in close association with the transition metals, such as $\mathrm{Cd}, \mathrm{Pb}, \mathrm{Ag}, \mathrm{Au}, \mathrm{Sb}, \mathrm{P}, \mathrm{W}$ and Mo (Smedley and Kinniburgh, 2002). Aside from mineralized zones, As is also found at high concentrations in rocks altered by hydrothermal solution. Hydrothermal solution, which is the hot, watery solution that escapes from magma during the latter stages of crystallization, can invade surrounding rocks and deposit the metallic ions that it contains (Tarbuck and Lutgens, 2002). Superheated groundwater, meteoric water or seawater in contact with active volcanic strata can also act like hydrothermal solution and alter its surrounding rock. A previous study by Tanaka (1998) confirmed that whenever rock is altered, it contains higher concentrations of metals and metalloids in comparison to the unaltered state.

The mobility of As in the environment is dependent largely on its chemical speciation. The dominant As species at a given time is controlled by many parameters, most notable of these include the $\mathrm{pH}$ and redox conditions of the system, precipitation and adsorption reactions, the source of As, and the presence of organic matter that drives reducing conditions (Brennan and Lindsay, 1996; Foster et al., 1998; Savage et al., 2000; Peters and Blum, 2003; O’Day et al., 2004). Our previous studies showed that As mobility from hydrothermally altered rock was highly $\mathrm{pH}$ dependent with higher leaching under acidic and alkaline conditions (Tabelin et al., 2008; Tabelin and Igarashi, 2009a). It was also proposed that the major mechanisms of As release from hydrothermally altered rock can be either one or more of the following: acid 
dissolution, reductive dissolution, ion exchange and sulfide oxidation processes depending on the pH, DO and redox conditions (Tabelin and Igarashi, 2009a). Our previous studies, however, were undertaken in the laboratory under controlled conditions. Those results are helpful in pointing out the parameters that are important for the mobilization of As from these sources but the conditions during the actual disposal are more complex. Therefore an in-situ experiment is necessary to extrapolate from the results already obtained regarding As mobilization from hydrothermally altered rock.

Groundwater contamination of As is a serious problem encountered in many parts of the world (Das et al., 1996; Nickson et al., 2000; Dowling et al., 2002; Akai et al., 2006). The use of As contaminated groundwater for drinking and cooking especially in developing rural areas without water treatment results in the ingestion of this toxic element into the body. Recent studies have shown that As is both a carcinogen and mutagen and that chronic exposure, that is exposure to small amounts of As every day, can cause cancers of the skin, lungs and kidneys (O'Day et al., 2004). In Japan, there is a new problem regarding the excavation of hydrothermally altered rock rich in As and other toxic elements during tunnel construction for railways and roads. If $\mathrm{As}$ and the other toxic elements such as $\mathrm{Se}, \mathrm{B}, \mathrm{Cr}$ and $\mathrm{Pb}$ would leach out from the rock, it will contaminate the surrounding soil and groundwater. In addition to the high content of toxic elements in the rock, it is also excavated in large quantities, which will become a source of constant toxic contaminants for a long period of time when disposed improperly. The excavated rocks are currently disposed in special landfills but this method is so expensive due to the large volume of the excavated rocks that alternative methods are currently being explored.

In this study, the mobility of As was elucidated using in-situ impoundment-type experiments by monitoring porewater and pond water chemistry, $\mathrm{O}_{2}$ composition, temperature 
and volumetric water content for about 2 years. The hydrothermally altered rock used was excavated at a nearby tunnel construction site. Different types of covering soil were used to reduce the $\mathrm{O}_{2}$ concentration and water infiltration into the impoundment. The low permeability of the soil cover could act as a barrier against oxidation and water infiltration that lowers the amount of As released from the waste rock. Other parameters such as $\mathrm{pH}$ and oxidationreduction potential (Eh) were also monitored. In addition, batch leaching experiments of the rock used in the impoundments were also conducted to compare the results of both controlled and insitu conditions. The data collected in this study will help in the greater understanding of As mobility from hydrothermally altered rock and assist in the design of an alternative disposal method of these potentially hazardous waste rock.

\section{MATERIALS AND METHODS}

\subsection{Chemical and mineralogical analysis}

The rock was crushed using a jaw crusher or agate mortar and sieved using a $2 \mathrm{~mm}$ aperture size screen. The crushed rock passing the screen was used as samples for the mineralogical and chemical analyses as well as the batch leaching experiments. The chemical compositions of the soil and waste rock samples used in the impoundments were measured using an energy dispersive X-ray fluorescence spectrometer, Xepos (Rigaku Corporation, Japan) while the mineral constituents of the rock were identified using an X-ray diffractometer, Multiplex (Rigaku Corporation, Japan). 


\subsection{Laboratory leaching experiments}

Batch leaching experiments were conducted by mixing 15 grams of crushed rock sample and $150 \mathrm{ml}$ of prepared solution for $24 \mathrm{hrs}$ at $120 \mathrm{rpm}$. The $\mathrm{pH}$ of the leachant was adjusted using hydrochloric acid $(\mathrm{HCl})$ or sodium hydroxide $(\mathrm{NaOH})$ solution. Filtered leachates $(0.45 \mu \mathrm{m}$ Millipore sterile filters) were collected after measuring the $\mathrm{pH}$ and Eh, acidified and stored at $6^{0} \mathrm{C}$ prior to the chemical analyses.

\subsection{Impoundment construction}

Four impoundments were built on site with rectangular base, truncated-pyramid structures as shown in Figure 1. Impoundment 1 was composed solely of the hydrothermally altered rock (slate) while impoundments 2, 3 and 4 were covered with different types of silty soil in order to minimize water and $\mathrm{O}_{2}$ intrusion into the rock. Wood chips were also added to the covering soil of impoundment 4 to induce reducing conditions because of the wood chips' decomposition. Details of the dimensions of each impoundment are illustrated in Figure 2. Sensor probes for $\mathrm{O}_{2}$ concentration, water content and temperature as well as porewater ceramic collecting cups were placed at key portions of each impoundment. For impoundment 1 without covering soil, the sensor probes were placed at depths of 0.5 and $1.5 \mathrm{~m}$ while impoundments with silty soil covering (impoundments 2,3 and 4) had probes at depths of $0.5 \mathrm{~m}$ (interface of the soil and rock layer) and $1.5 \mathrm{~m}$ (in the rock layer). A pipe was also placed at the bottom of each impoundment to collect the seepage (Figure 3). The pipe tip was fitted with a U-tube in order to avoid $\mathrm{O}_{2}$ intrusion from the bottom (Figure 3). Throughout the remainder of the paper, impoundment 1 is referred to as case 1 , impoundment 2 as case 2 , impoundment 3 as case 3 and impoundment 4 as case 4 . Porewater samples were also collected at depths of 0.5 and $1.5 \mathrm{~m}$ as 
well as the leachate sample from the bottom of each impoundment (Figure 3). Seepage from the bottom of the impoundment and run-off water plus leachate from the site collected in a pond were also sampled and analyzed.

\subsection{Chemical Analysis}

Dissolved As concentrations greater than $0.1 \mathrm{mg} / \mathrm{L}$ were analyzed using an inductively coupled plasma atomic emission spectrometer (ICP-AES) (Shimadzu Corporation, Japan). If the concentration of As is lower than $0.1 \mathrm{mg} / \mathrm{L}$, the hydride generation process coupled with the ICP-AES was used. Concentrations of coexisting ions were also measured using ICP-AES, cation chromatograph and anion chromatograph. The results of the analyses using ICP-AES had a margin of error of about 2-3\% while the hydride generation process for low As concentration had an uncertainty of about $5 \%$.

\section{RESULTS AND DISCUSSION}

\subsection{Properties of waste rock and soil cover}

The rock sample used in these experiments was a metamorphic rock of sedimentary origin called slate. According to Smedley and Kinniburgh (2002), the As concentration in metamorphic rocks tend to reflect the concentrations in their igneous and sedimentary precursors. A summary of the mineral constituents and chemical composition of the rock is shown in Tables 1 and 2. These tables indicate that the As content is slightly higher than the average As concentration of sedimentary rocks at $10.5 \mathrm{mg} / \mathrm{kg}$ (average As content of sedimentary rock is around 5 to $10 \mathrm{mg} / \mathrm{kg}$ (Webster, 1999)). The sample also contains calcite, which could account

for the alkaline $\mathrm{pH}$ of the sample when in contact with water. Sulfur content is also appreciable at $0.27 \%$ but As bearing-sulfide minerals such as arsenopyrite (FeAsS), orpiment $\left(\mathrm{As}_{2} \mathrm{~S}_{3}\right)$ or 
realgar (AsS) were not detected by the XRD analysis which could indicate that As is present either as substitional (with sulfur), interstitial or in the adsorbed phase. The analyses summarized in Tables 1 and 2 are from the bulk waste rock and pyrite was not detected. However, XRD analysis of individual boring core samples during the tunnel construction detected the presence of pyrite in some of the samples (Table 3). Therefore, it is safe to assume that pyrite is present in the waste rock although in small amounts.

Important physical properties of the waste rock and the covering soil used in the in-situ experiment are listed in Table 4. The waste rock has a hydraulic conductivity of $3.22 \times 10^{-2} \mathrm{~cm} / \mathrm{s}$ that is about 100 times higher than the covering soil used. The permeability of the soil and rock is important because this property determines the quantity and retention time of water percolating into the system. The retention time influences the interaction between water and waste rock that in turn affects the mobility of toxic elements such as As. The low permeability of the soil cover would result in lesser amounts of water percolating into the waste rock. The permeability of the soil will also determine the amount of atmospheric oxygen that can penetrate into the impoundment.

\subsection{Relationship between $\mathrm{pH}, \mathrm{Eh}, \mathrm{As}, \mathrm{Fe}$ and $\mathrm{SO}_{4}{ }^{2-}$ concentration}

The trends of the $\mathrm{pH}$ for cases 1,2 and 3 were identical in that the porewater $\mathrm{pHs}$ were between 9 and 11.5 independent of depth as presented in Figure 4. For case 4, however, the $\mathrm{pH}$ of the porewater at a depth of $0.5 \mathrm{~m}$ fell between 7.5 and 9.5 , which was lower compared to the other cases (Figure 4). The $\mathrm{pH}$ of the porewater at a depth of $1.5 \mathrm{~m}$ in case 4 increased and approached the range of 9 and 11. The source of the acidity in this case was most probably the decomposing wood chips mixed with the covering soil. The presence of calcite in the waste rock 
neutralized the acidity, and as the porewater percolated downward the alkalinity increased, leading to a higher porewater $\mathrm{pH}$ at $1.5 \mathrm{~m}$ than at $0.5 \mathrm{~m}$ in case 4 .

The As concentration trends were similar in all 4 cases, that is, the concentration of As in the porewater increased with depth as shown in Figure 5. As water percolates down the impoundment, it comes in contact with "fresh" waste rock thereby increasing it's As load. This in turn resulted to a higher As concentration at the bottom than the top portions of the impoundment. Similar to $\mathrm{pH}$, Eh was also independent of the depth as shown in Figure 6. These results indicate that the $\mathrm{pH}$ and $\mathrm{Eh}$ of the system are relatively uniform throughout the impoundment. However, the Eh gradually increased with the elapsed time. This suggests that the oxidation reactions or oxygen consumption reactions in the rock layer was fast at the beginning of the experiment and gradually decreased with time. The sulfate $\left(\mathrm{SO}_{4}{ }^{2-}\right)$ concentration change with time is presented in Figure 7. The change in As and $\mathrm{SO}_{4}{ }^{2-}$ concentration in the porewater corresponded to sulfide oxidation during the early part of the experiment. This means that inside the impoundment, faster oxidation of sulfide minerals favors more As mobilization. Our previous paper from batch leaching experiments also showed that increased oxidation of sulfide minerals at alkaline $\mathrm{pH}$ increased the amount of As mobilized from the rock (Tabelin and Igarashi, 2009a). Positive correlation between $\mathrm{Fe}$ and As was also observed during the in-situ experiments, which suggests that the dissolution of Fe bearing minerals and the release of As from the waste rock may have occurred simultaneously. Another interesting observation during the in-situ experiment was the positive correlation between $\mathrm{SO}_{4}{ }^{2-}$ and As concentration in the leachate especially at lower depths $(1.5 \mathrm{~m})$ as shown in Figures 5 and 7 . Since $\mathrm{SO}_{4}{ }^{2-}$ is the product of the oxidation of sulfide minerals, its presence in the porewater indicates the oxidation of sulfide minerals contained in the waste rock. Water and oxygen are necessary for sulfide oxidation, and in the 
process oxygen is used up and $\mathrm{SO}_{4}{ }^{2-}$ is evolved as explained by the oxidation of pyrite in the following reactions:

$$
\begin{array}{rlr}
\mathrm{FeS}_{2(\mathrm{~s})}+15 / 4 \mathrm{O}_{2(\mathrm{~g})}+5 / 2 \mathrm{H}_{2} \mathrm{O} \longrightarrow \mathrm{FeOOH}_{(\mathrm{s})}+2 \mathrm{H}_{2} \mathrm{SO}_{4(\mathrm{aq})} & \text { Equation (1) } \\
2 \mathrm{FeS}_{2(\mathrm{~s})}+15 / 2 \mathrm{O}_{2(\mathrm{~g})}+4 \mathrm{H}_{2} \mathrm{O} & \longrightarrow \mathrm{Fe}_{2} \mathrm{O}_{3(\mathrm{~s})}+4 \mathrm{H}_{2} \mathrm{SO}_{4(\mathrm{aq})} & \text { Equation (2) } \\
\mathrm{FeS}_{2(\mathrm{~s})}+15 / 4 \mathrm{O}_{2(\mathrm{~g})}+7 / 2 \mathrm{H}_{2} \mathrm{O} & \longrightarrow \mathrm{Fe}(\mathrm{OH})_{3(\mathrm{~s})}+2 \mathrm{H}_{2} \mathrm{SO}_{4(\mathrm{aq})} & \text { Equation (3) }
\end{array}
$$

However, sulfide oxidation may not have been the major mechanism controlling As mobility under these conditions since desorption/adsorption as well as precipitation of metal oxides and oxyhydroxides that can release/scavenge As are also prevalent at alkaline $\mathrm{pH}$. The combined seepage and run-off water collected in a pond was also sampled and analyzed. The results show similar trends in $\mathrm{As}$ and $\mathrm{SO}_{4}{ }^{2-}$ concentrations in the leachate as a function of $\mathrm{pH}$, indicating that the mobility of As can be predicted using $\mathrm{SO}_{4}{ }^{2-}$ concentration in the pond water as an indicator (Figure 8). The pond was designed to collect all the water from the four impoundments (, i.e., seepage and surface run-off) in which dilution during rainy season and concentration during the dry season were to be expected. This explains why the pond water $\mathrm{pH}$ was more variable than that of the porewater in the impoundments. Figure 9 shows that the concentration of As in the pond increased when the amount of rainfall was low and consequently decreased when rainfall increased. Therefore, the pond water quality is a clear indication of concentration decrease by dilution or increase by concentration due to excess evaporation.

\subsection{Effect of covering soil on the $\mathrm{pH}$, Eh and As concentration}

The covering soil used in the impoundment influenced $\mathrm{As}$ and $\mathrm{SO}_{4}{ }^{2-}$ concentrations in the porewater although it did not influence the $\mathrm{pH}$ and Eh significantly (Figures 4, 5, 6 and 7). All covering soil in general decreased the As concentration in the porewater as shown in Figure 5. 
Without any soil cover, the As concentration of the bottom porewater ranged from 20 to $25 \mu \mathrm{g} / \mathrm{L}$ regardless of the season. After covering the impoundment with less permeable soils, the amount of As in the porewater decreased to below $10 \mu \mathrm{g} / \mathrm{L}$. These results indicate that a silty covering soil would effectively reduce the amount of As mobilized from the rock by preventing the direct exposure of the rock to the atmosphere.

\subsection{Effect of the season on $\mathrm{O}_{2}$, temperature, water content, Eh and As concentration}

The island of Hokkaido in Japan has four seasons (winter, spring, summer and fall) that affect the parameters important in the mobility of As from the in-situ impoundment experiments. Figure 10 presents the $\mathrm{O}_{2}$ concentration and temperature measurements under ambient conditions and that of the porewater at depths of 0.5 and $1.5 \mathrm{~m}$. Some points are missing in the plots of temperature and $\mathrm{O}_{2}$ concentration (January 2007 and February - May 2007) in Figure 10 due to electrical power failures. During winter (December - April) all the impoundments are covered with thick snow and ice with outside temperatures of less than $0^{0} \mathrm{C}$ such that minimal amount of water and $\mathrm{O}_{2}$ percolates into the waste rock. Sampling done before the impoundments were completely covered with snow around November and immediately before the complete thawing of the snow around April showed that As concentration decreased. Initial $\mathrm{O}_{2}$ concentration varied per case and depth but were all lower than the $21 \% \mathrm{O}_{2}$ concentration typical of a system in equilibrium with the atmosphere; $15 \%$ for both 0.5 and $1.5 \mathrm{~m}$ in case $1,7 \%$ and $19 \%$ for 0.5 and $1.5 \mathrm{~m}$, respectively for case $2,5 \%$ for both 0.5 and $1.5 \mathrm{~m}$ in case 3 , and $15 \%$ for $1.5 \mathrm{~m}$ in case 4 . The $\mathrm{O}_{2}$ concentration in case 1 started to increase initially until about $17.5 \%$ was reached, and then it remained at that level throughout winter. As the water started to percolate into the impoundment at the beginning of spring, $\mathrm{O}_{2}$ concentration at $0.5 \mathrm{~m}$ fluctuated more but never fell below $15 \%$. In contrast, the $\mathrm{O}_{2}$ concentration at $1.5 \mathrm{~m}$ dramatically decreased with a lowest 
reading of about $10 \%$ around July. The difference in the $\mathrm{O}_{2}$ concentration at depths of 0.5 and $1.5 \mathrm{~m}$ could be attributed to the utilization of $\mathrm{O}_{2}$ in the oxidation of sulfide minerals present in the waste rock as the amount of water percolating into the impoundment increased. Aside from the decrease in $\mathrm{O}_{2}$ concentration, $\mathrm{SO}_{4}{ }^{2-}$ concentration also increased dramatically in case 1 at 1.5 $\mathrm{m}$ as illustrated in Figure 7. Igarashi et al. (2006) reported that the decrease of $\mathrm{O}_{2}$ concentration in a water-rock with pyrite system was due to the oxidation of sulfide minerals. As mentioned earlier, although pyrite in the bulk waste rock was not quantified by XRF because of dilution, analyses of core samples confirmed the presence of pyrite in the rock. The trend of $\mathrm{O}_{2}$ concentration for case 1 further implies the presence of pyrite in the bulk rock as seen by the decrease in the $\mathrm{O}_{2}$ from April to November 2006. This trend was not observed the following year as shown in Figure 7 where the $\mathrm{O}_{2}$ concentration at 0.5 and $1.5 \mathrm{~m}$ were similar. These $\mathrm{O}_{2}$ concentration trends suggest that the small quantity of sulfide minerals present in the rock (Table 3) may have been used up during the early part of the experiment such that after a year, the $\mathrm{O}_{2}$ concentration in the impoundment did not vary with depth.

Case 2 shows an interesting result of $\mathrm{O}_{2}$ concentration change. In comparison to case 1 (no soil cover) the trend of $\mathrm{O}_{2}$ concentration with depth was reversed, that is, the $\mathrm{O}_{2}$ at bottom $(1.5 \mathrm{~m})$ was higher than at the top $(0.5 \mathrm{~m})$ throughout the experiment. Initially, $\mathrm{O}_{2}$ concentration at the bottom was high at about $19 \%$ and fluctuated throughout winter, but never dropped below $15 \%$. This could be because the bottom part of the impoundment did not have enough water for sulfide oxidation to occur due to the initial condition during the impoundment construction. It is also possible that $\mathrm{O}_{2}$ from the air penetrated the impoundment from the bottom via the pipe used for seepage collection. A thorough inspection of the impoundments after winter showed that some of the seepage pipes were broken and had to be replaced. On the other hand, the $\mathrm{O}_{2}$ 
concentration at $1.5 \mathrm{~m}$ was lower at about $7 \%$, and then started to fluctuate throughout winter reaching a peak at about $15 \%$. Around April, when water started to percolate substantially into the impoundment and temperature started to rise, the $\mathrm{O}_{2}$ concentration at both 0.5 and $1.5 \mathrm{~m}$ decreased until about 1\%. The soil cover minimized water and oxygen intrusion into the impoundment, causing most of the $\mathrm{O}_{2}$ initially present to be used up. The $\mathrm{SO}_{4}{ }^{2-}$ concentration in the porewater was also considerably low compared to case 1, indicating a reduction in the oxidation of sulfide-minerals (Figures 7). When the second winter came, the $\mathrm{O}_{2}$ concentration at both depths $(0.5$ and $1.5 \mathrm{~m})$ started to increase approximately around the previous winter's level of about $15 \%$.

Case 3 shows a similar trend to case 2 with respect to the $\mathrm{O}_{2}$ concentration with depth. However, the $\mathrm{O}_{2}$ content initially at 0.5 (about 4\%) and $1.5 \mathrm{~m}$ (about 6\%) did not differ considerably. This trend started to reverse around May when the $\mathrm{O}_{2}$ concentration at $0.5 \mathrm{~m}$ became higher than the concentration at the bottom, which was consistent with the increase in the percolation of oxygenated water due to rain. Fluctuations in $\mathrm{O}_{2}$ concentration at both depths were also evident at these periods, which were influenced both by the percolation of water and the utilization of available $\mathrm{O}_{2}$ by sulfide oxidation.

For case $4, \mathrm{O}_{2}$ sensor error was experienced initially at a depth of $0.5 \mathrm{~m}$ until the end of winter (end of April) and had to be repaired. A similar trend was observed between case 4 and case 1 , that is, the upper portion of the impoundment had a higher $\mathrm{O}_{2}$ concentration than the bottom part. However, the fluctuations observed during periods of rain were greater in case 4 than in case 1 especially at $0.5 \mathrm{~m}$. The presence of a covering soil caused the sudden rise and fall in the $\mathrm{O}_{2}$ concentration during the months with rain. In general, lower concentrations of $\mathrm{O}_{2}$ in the impoundment especially during the months with rain (April - November) was due to the 
oxidation of sulfide minerals in the waste rock and the reduction in the amount of $\mathrm{O}_{2}$ intrusion because of the presence of a silty covering soil.

Results of volumetric water content were only available for case 2 because probe malfunction was experienced in cases 1, 3 and 4. Figure 11 illustrates the change in volumetric water content in case 2 throughout the in-situ experiment. During winter, the volumetric water content was relatively constant while the temperature ranged between $2^{\circ} \mathrm{C}$ and $8^{0} \mathrm{C}$ (Figures 10 and 11). The water content in the top part $(0.5 \mathrm{~m})$ of the impoundment was always higher than that in the bottom $(1.5 \mathrm{~m})$. This is due to the higher porosity of the covering soil at $55.1 \%$ compared to that of the rock at $27.1 \%$. The results indicate that the covering soil was subsaturated throughout the experiment with water content ranging from 25 to $30 \%$. The waste rock was also sub-saturated at the start of the experiment and throughout winter with water content between 20 and $25 \%$. However, as the water started to percolate into the impoundment after winter, water content increased until saturation was reached at about $27.1 \%$. The saturated state was not maintained because of the high hydraulic conductivity of the rock so that throughout the period with rainfall, the water content rose and fell between saturated (27.1\%) and sub-saturated state $(21 \%)$. Based on these results, the use of a covering soil has two mechanisms of reducing the leaching of As from the waste rock: first, the covering soil acts like a barrier reducing $\mathrm{O}_{2}$ and water intrusion into the waste rock; second, the covering soil functions like a sponge, collecting water and slowly releasing it to the waste rock as it gets saturated. The lower amount of water and $\mathrm{O}_{2}$ in contact with the waste rock would lower the amount of As released from the rock by decreasing the water-rock- $\mathrm{O}_{2}$ interaction.

The redox potential at the start of the in-situ experiment was reducing in all cases but slowly increased to oxidizing conditions (Figure 6). Although the condition at the start was 
reducing, increased sulfate $\left(\mathrm{SO}_{4}{ }^{2-}\right)$ concentration at a depth of $1.5 \mathrm{~m}$ was observed around the time when the precipitation as rain increased (Figure 7). This could be because oxygen was still introduced into the system with the percolating rain water, allowing the oxidation of sulfide minerals to continue.

The concentration of As in the porewater at a depth of $0.5 \mathrm{~m}$ was also highest around August 2006 when conditions were reducing, the temperature was higher and the $\mathrm{O}_{2}$ concentration was lower. Case 1 had a constant As leaching concentration independent of the month while case 3 showed a peak around July (Figure 5). These results suggest that other than the $\mathrm{pH}$ and $\mathrm{Eh}$, the temperature and water content also have impacts on the mobilization of As from hydrothermally altered rocks. Figure 12 shows the dependence of As concentration with the amount of rainfall especially at lower depth $(0.5 \mathrm{~m})$. However, this relationship between rainfall and As concentration was not observed at a higher depth $(1.5 \mathrm{~m})$. Laboratory column experiments showed that a higher infiltration rate increased the mobility of As, both quantity and rate, from hydrothermally altered rock of sedimentary origin (Tabelin and Igarashi, 2009b). The infiltration rate during the in-situ experiments was a function of the rainfall, temperature, presence or absence of soil cover and the permeability of the soil cover and rock. Thus, these parameters could greatly affect the mobility of As from the rock in the impoundment. Rain induces the leaching of As and the use of a soil cover with low permeability shows promise in the safe disposal of hydrothermally altered rocks by reducing water and oxygen intrusion. However, soil covering was insufficient to immobilize As as seen in the results of this study (Figure 5), in which As concentration in the porewater reached about $30 \mu \mathrm{g} / \mathrm{L}$ in case 3 at around the time when the precipitation as rain was high (July). To prevent this high As concentration 
porewater from seeping out of the impoundment, a bottom soil layer with As adsorption properties would be helpful.

\subsection{Mechanisms controlling the mobility of As in the in-situ experiment}

The main factors controlling As mobilization from hydrothermally altered rock are the pH, Eh and DO (Tabelin and Igarashi, 2009a). These three major paramaters further control the major modes of As release from the rock that include precipitation, desorption/adsorption, oxidation/reduction and dissolution processes. The in-situ experiments were conducted under alkaline and from mildly reducing to oxidizing conditions as indicated by the $\mathrm{pH}$ and $\mathrm{Eh}$ of the porewater. Under these conditions, the major potential mechanisms of As release could be desorption/adsorption reactions (with clays and metal oxides), the As (III)/As (V) redox reactions, sulfide oxidation and precipitation of calcium arsenates/arsenites (Dutre and Vandecasteele, 1995). To understand the speciation of As under the in-situ conditions, a figure showing the Eh-pH diagram with the porewater samples collected from the impoundments was constructed using The Geochemist's Workbench ${ }^{\circledR}$ (Figure 13). The parameters used in the construction of the Eh-pH diagram were based on the actual chemical composition of the porewater collected from the impoundments (activity $(\mathrm{As})=10^{-7}$; activity $\left.\left(\mathrm{SO}_{4}{ }^{2-}\right)=10^{-3}\right)$. Based on this diagram, the major As specie in the system was $\mathrm{HAsO}_{4}{ }^{2-}$, which means that the dissolved As were mostly in the +5 oxidation state. This indicates that thermodynamically, the redox condition in the impoundments was insufficient for the reduction of As (V) to As (III). The reduction of As (V) to As (III) can release more As because As (III) is more mobile than As (V) as reported in the literature (De Vitre et al., 1991; Smedly and Kinniburgh, 2002). Thus, mobilization of As via the reduction of As (V) to As (III) would be minimal. With regards to the precipitation of calcium arsenates/arsenites, it has been reported in literature that calcium 
arsenite $\left(\mathrm{CaHAsO}_{3}\right)$ is more soluble than calcium arsenates (Cornelis et al., 2008). Calcium arsenite is stable at hyper alkaline conditions between 11.91 and 12.75 (Dutre and Vandecasteele, 1995) while calcium arsenates, including its hydrated forms, e.g. $\mathrm{Ca}_{5}\left(\mathrm{AsO}_{4}\right)_{3} \mathrm{OH}$, $\mathrm{Ca}_{3}\left(\mathrm{AsO}_{4}\right)_{2} \cdot 3 \mathrm{H}_{2} \mathrm{O}, \mathrm{Ca}_{4}(\mathrm{OH})_{2}\left(\mathrm{AsO}_{4}\right)_{2} \cdot 4 \mathrm{H}_{2} \mathrm{O}$ and $\mathrm{CaHAsO}_{4} \cdot 4 \mathrm{H}_{2} \mathrm{O}$, are stable on a wider $\mathrm{pH}$ range of about 3 to 12.5 (Bothe and Brown, 1999; Zhu et al., 2006). The saturation indices (SI) of the porewater samples were calculated using PHREEQC (Parkhurst and Appelo, 1999) with the THERMODEM database compiled by the French Geological Survey (BRGM Institute) to predict whether precipitation of $\mathrm{Al} / \mathrm{Fe}$ oxides, clay minerals and calcium arsenates were thermodynamically possible. Thermodynamic data and chemical reactions of four calcium arsenates used in the calculations were obtained from Zhu et al. (2006) and Bothe and Brown (1999). The results suggest that the porewaters were undersaturated with respect to calcium arsenates while oxides of iron (goethite, hematite and $\mathrm{Fe}(\mathrm{OH})_{3}$ ), aluminum (diaspore and gibbsite), carbonates (calcite and dolomite) and clay minerals (hydrotalcite) were precipitating at both depths of 0.5 and $1.5 \mathrm{~m}$ as shown in Figures 14 and 15. Sequential extraction of the rock (the method used is a modified version of that developed by Tessier et al. (1974) and is discussed in our previous paper (Tabelin and Igarashi, 2009a)) showed that As was associated mostly in the exchangeable phase (42.9\%) followed by Fe-Mn oxides (31.3\%), residual (23\%) and carbonates (2.8\%). The increase of electrostatic repulsion on negatively charged mineral surfaces in the rock under alkaline conditions could result in the desorption of exchangeable As phases (Fuller et al., 1993). However, a portion of the desorbed As can be coprecipitated with or re-adsorbed onto Fe and Al oxyhydroxides or oxides, carbonates and clay minerals. Our results suggest that the major mechanism controlling As release is linked to the desorption of adsorbed/exchangeable As phases and its subsequent coprecipitation with or re-adsorption to $\mathrm{Fe}$ and $\mathrm{Al}$ oxides and 
oxyhydroxides, carbonates and clay minerals. The adsorption of As and other oxyanions onto Al and Fe oxides, carbonates and clay minerals such as hydrotalcite has been extensively covered in literature. The adsorption capacity of $\mathrm{Fe}$ and $\mathrm{Al}$ oxides and oxyhydroxides as well as clays has been shown to decrease with increasing $\mathrm{pH}$ but they are nonetheless capable of adsorbing As and other oxyanions under alkaline conditions (Gosh and Teoh, 1985; Dzombak and Morel, 1990; Lin and Puls, 2000; Dousova et al., 2003; Wang and Mulligan, 2006; Cornelis et al., 2008). Aside from the metal oxides and clays, carbonates such as calcite and dolomite have also been reported to scavenge oxyanions from solutions up to $\mathrm{pH} 12$ and can affect the concentration of As under alkaline conditions where they are abundant (Goldberg and Glaubig, 1988; RomanRoss et al., 2002). Under alkaline conditions, it is also important to consider the increase of sulfide mineral oxidation since these minerals can also release their associated As content (Tabelin and Igarashi, 2009a). However, although boring core samples showed that sulfide minerals such as pyrite were present in the waste rock (Table 3), its concentration was too low in the bulk rock used during the in-situ experiments to be detected by XRF analysis. Its influence is therefore only secondary to coprecipitation/re-adsorption and adsorption/desorption reactions.

\subsection{Comparison of As leaching between in-situ and laboratory conditions}

Our previous studies using hydrothermally altered rock of varying types have shown that As mobility depends on the $\mathrm{pH}$ and that higher leaching is expected at more alkaline and more acidic pH (Tabelin et al., 2008; Tabelin and Igarashi, 2009a; Tabelin and Igarashi, 2009b). The results of the laboratory batch leaching experiments supplemented these previous results as illustrated in Figure 16. It is also observed in the figure that the in-situ results show lower As concentration than the results in the laboratory. This indicates that although in-situ experiments are more complex, laboratory results can be used to predict the upper limit of As concentration 
that will leach out from the waste rock at a given $\mathrm{pH}$. These would be helpful in the determination of the amount of adsorbent that will be used in the bottom layer during the disposal of the waste rock when using a combination of silty covering soil and bottom adsorption layer as a disposal method.

\section{CONCLUSIONS}

This study was conducted to elucidate the factors affecting the mobility of As under insitu conditions and to explore the effectiveness of using a silty soil cover to minimize As leaching from hydrothermally altered rock. The mobility of As was highly dependent on the season especially in the island of Hokkaido where rain is only available during spring, summer and autumn months. The highest concentration of As was observed during the months with rain, when enough water percolated into the impoundment. The highest As concentration was also observed at the beginning of the experiment when the conditions were reducing and gradually decreased as the conditions became more oxidizing. Based on the experimental and calculated results with PHREEQC, the mobility of As from the rock is controlled by desorption/adsorption as well as coprecipitation/re-adsorption processes with $\mathrm{Fe}$ and $\mathrm{Al}$ oxides/oxyhydroxides, carbonates and clay minerals. The use of a silty soil cover of low permeability effectively lowered the As concentration in the porewater, but it was not enough to reduce the leaching of As because the conditions inside the impoundment could be dynamic and could change with time. In order to safeguard during such unexpected changes, a bottom As adsorption layer would be helpful to immobilize any leached As from the waste rock. The amount of adsorbent needed for such a system can be estimated using a $\mathrm{pH}$ versus As concentration diagram that shows the amount of As released with $\mathrm{pH}$ from batch leaching experiments of the hydrothermally altered rock. 


\section{Acknowledgements}

The authors wish to thank Asahikawa Development and Construction Department of Hokkaido Regional Development Bureau for supporting the in-situ impoundment experiments. The inputs of the anonymous reviewers were also greatly appreciated.

\section{References}

Akai, J., Izumi, K., Fukuhara, H., Masuda, H., Nakano, S., Yoshimura, T., Ohfuji, H., Anwar, H.M. and Akai, K., Mineralogical and geomicrobial investigations on groundwater arsenic enrichment in Bangladesh. Applied Geochemistry, 2004, 19, 215-230.

Bothe Jr., J.V. and Brown, P.W., The stabilities of calcium arsenates at $23 \pm 1{ }^{0} \mathrm{C}$. Journal of Hazardous Materials, 1999, B69, 197-207.

Brennan, E.W. and Lindsay, W.L., The role of pyrite in controlling metal ion activities in highly reduced soils. Geochim. Cosmochim. Acta, 1996, 60 (19), 3609-3618.

Cornelis, G., Anette-Johnson, C., Van Gerven, T. and Vandecasteele, C., Leaching mechanisms of oxyanionic metalloid and metal species in alkaline solid wastes: A review. Applied Geochemistry, 2008, 23, 955-976.

Das, D., Samanta, S., Mandal, B.K., Chowdhury, T.R., Chanda, C.R., Chowdry, P.P., Basu, K. and Chakraborti, D., Arsenic in groundwater in six districts of West Bengal, India. Environmental Geochemistry and Health, 1996, 18, 5-15.

De Vitre, R., Belzile, N. and Tessier, A., Speciation and adsorption of arsenic on diagenetic iron oxyhydroxides. Limnol. Oceanog., 1991, 36, 1480-1485.

Dousova, B., Machovic, V., Kolousek, D., Kovanda, F. and Dornicak, V., Sorption of As (V) species from aqueous solution. Water Air and Soil Pollution, 2003, 149, 251-267.

Dowling, C.B., Poreda, R.J., Basu, A.R., Peters, S.L. and Aggarwal, P.K., Geochemical study of arsenic release mechanisms in the Bengal Basin groundwater. Water Resources Research, 2002, 38(9), 1173.

Dutre, V. and Vandecasteele, C., Solidification/stabilization of arsenic-containing waste: Leach tests and behavior of arsenic in the leachate. Waste Management, 1995, 15(1), 55-62.

Dzombak, D.A. and Morel, F.M.M., Surface complexation modeling: Hydrous ferric oxide, 1990, John Wiley and Sons, New York. 
Foster, A.L., Brown, G.E., Tingle, T.N. and Parks, G.A., Quantitative arsenic speciation in mine tailings using X-ray absorption spectroscopy. American Mineralogist, 1998, 83, 553-568.

Fuller, C.C., Davis, J.A. and Waychunas, G.A., Surface-chemistry of ferrihydrite. 2. Kinetics of arsenate adsorption and coprecipitation. Geochim. Cosmochim. Acta, 2003, 57, 2271-2282.

Ghosh, M.M. and Teoh, R.S., Adsorption of arsenic on hydrous aluminum oxide. In Proc. $7^{\text {th }}$ Mid-Atlantic Industrial Waste Conference, Lancaster, PA, 1985, 139-155.

Goldberg, S. and Glaubig, R.A., Anion sorption on a calcareous, montmorillonitic soil - arsenic. Soil Sci. Soc. Am. J., 1988, 52, 1297-1300.

Igarashi, T., Saito, R., Sarashina, M. and Asakura, K., Impoundment of excavated pyrite-bearing rocks using silty covering soil. Clay science, 2006, 12, 143-148.

Lin, Z. and Puls, R.W., Adsorption, desorption and oxidation of arsenic affected by clay minerals and aging process. Environmental Geology, 2000, 39(7), 753-759.

Nickson, R.T., McArthur, K.M., Ravenscroft, J.M., Burgess, W.G. and Ahmed, K.M., Mechanism of arsenic release to groundwater, Bangladesh and West Bengal. Applied Geochemistry, 2000, 15, 403-413.

O’Day, P.A., Vlassopoulos, D., Root, R. and Rivera, N., The influence of sulfur and iron on dissolved arsenic concentrations in the shallow subsurface under changing redox conditions. Proceedings of the National Academy of Sciences, 2004, 101 (38), $13703-13708$.

Parkhurst, D.L. and Appelo, C.A.J., User's Guide to PHREEQC (Version 2) - A computer program for speciation, batch-reactions, one-dimensional transport, and inverse geochemical calculations, U.S. Geological Survey, Denver, CO, 1999.

Peters, S.C. and Blum, J.D., The source and transport of arsenic in a bedrock aquifer, New Hampshire, USA. Applied Geochemistry, 2003, 18, 1773-1787.

Roman-Ross, G., Cuello, G., Tisserand, D. and Charlet, L., Arsenic removal by gypsum and calcite: The continuum between sorption and solid-solution phenomenon. Geochim. Cosmochim. Acta, 2002, 66, A646.

Savage, K.S., Tingle, T.N., O’Day, P.A., Waychunas, G.A. and Bird, D.K., Arsenic speciation in pyrite and secondary weathering phases, Mother Lode Gold District, Tuolumne County, California. Applied Geochemistry, 2000,15, 1219-1244.

Smedley, P.L. and Kinniburg, D.G., A review of the source, behavior and distribution of arsenic in natural waters. Applied Geochemistry, 2002, 17, 517-568.

Tabelin, C.B. and Igarashi, T. Mechanisms of arsenic and lead release from hydrothermally altered rock. Journal of Hazardous Materials, 2009a, 169, 980-990. 
Tabelin, C. B. and Igarashi, T., Mobility of arsenic from hydrothermally altered rock in laboratory column experiments: Effects of water and infiltration rate and compaction. In Proc. $3^{\text {rd }}$ International Workshop and Conference on Earth Resources and Technology. Sapporo, Japan, 2009b, CD-ROM.

Tabelin, C.B., Igarashi, T. and Asakura, K., Effect of $\mathrm{pH}$ on the mobilization of arsenic from hydrothermally altered rocks. In Proc. Water Down Under 2008 Incorporating 31st Hydrology and Water Resources Symposium and the 4th International Conference on Water Resources and Environment Research. Adelaide, Australia, 2008, pp. 2789-2797.

Tanaka, T., Distribution of arsenic in the natural environment with emphasis on rocks and soils. Applied Organometallic Chemistry, 1988, 2(4), 283-295.

Tarbuck, E.J. and Lutgens, F.K., Earth: An Introduction to Physical Geology, 7th ed., 2002, Prentice Hall, New Jersey.

Tessier, A., Campbell, G.C. and Bison, M., Sequential extraction procedure for the speciation of particulate trace metals, Anal. Chem., 1979, 51, 844-850.

Wang, S. and Mulligan, C., Natural attenuation processes for remediation of arsenic contaminated soils and groundwater. Journal of Hazardous Materials, 2006, 459-470.

Webster, J.G., Arsenic. In Encyclopaedia of Geochemistry, ed. C.P. Marshall and R.W. Fairbridge. Chapman Hall, London, 1999, pp. 21-22.

Zhu, Y.N., Zhang, X.H., Xie, Q.L., Wang, D.Q. and Cheng, G.W., Solubility and stability of calcium arsenates at $25{ }^{\circ} \mathrm{C}$. Water, Air and Soil Pollution, 2006, 169, 221-238. 


\section{FIGURE CAPTIONS}

FIGURE 1 Impoundments without covering soil (a) and with covering soil (b)

FIGURE 2 Physical dimensions of each impoundment; (a) case 1 (without covering soil), (b) cases 2, 3 and 4 (with covering soil)

FIGURE 3 Location of different sensor probes inside the impoundment; (a) without covering soil (case 1), (b) with covering soil (cases 2,3 and 4); $\mathrm{O}_{2}$ probe $(\square)$, water content probe $(\xi)$, porewater extraction ceramic cup $(\triangle)$ and temperature sensor (凸)

FIGURE 4 pH change with time (month-year); case 1 (a), case 2 (b), case 3 (c) and case 4 (d)

FIGURE 5 Change in As concentration with time (month-year); case 1 (a), case 2 (b), case 3 (c) and case 4 (d)

FIGURE 6 Change in redox potential with time (month-year); at a depth of $0.5 \mathrm{~m}$ (a) and at a depth of $1.5 \mathrm{~m}(\mathrm{~b})$

FIGURE 7 Changes in $\mathrm{SO}_{4}{ }^{2-}$ concentration of the porewater at 0.5 and $1.5 \mathrm{~m}$ with time (month-year); case 1 (a), case 2 (b), case 3 (c) and case 4 (d)

FIGURE 8 Changes in $\mathrm{As}$ and $\mathrm{SO}_{4}{ }^{2-}$ concentrations as a function of $\mathrm{pH}$ in the pond water

FIGURE 9 Changes in the As concentration of the pond water and the amount of rainfall with time (March 2006 - August 2007)

FIGURE 10 Changes in $\mathrm{O}_{2}$ concentration with time (December 2005 - July 2007) at 0.5 and $1.5 \mathrm{~m}$ of cases 1, 2, 3 and 4 (a); Changes in temperature with time (December 2005 - July 2007) at 0.5 and 1.5 m of cases $1,2,3$ and 4 (b)

FIGURE 11 Changes in the volumetric water content with time at 0.5 and $1.5 \mathrm{~m}$ of case 2

FIGURE 12 Changes in the As concentration of the pore water and the amount of rainfall with time (March 2006 - August 2007) at $0.5 \mathrm{~m}$ (a) and $1.5 \mathrm{~m}$ (b) of case 1

FIGURE 13 Eh-pH predominance diagram of As at $25{ }^{0} \mathrm{C}, 1.013$ bars, activity (As) $=10^{-7}$, activity $\left(\mathrm{SO}_{4}{ }^{2-}\right)=10^{-3}$. Porewater samples are represented by points; Case $1(\mathrm{G})$, Case $2(\boldsymbol{\Delta})$, Case $3(*)$ and Case $4(\bullet)$

FIGURE 14 Saturation indices of $\mathrm{Fe}$ and $\mathrm{Al}$ oxides, carbonates, clay minerals and calcium arsenate with time at a depth of $0.5 \mathrm{~m}$ for cases 1(a), 2(b), 3(c) and 4(d); Calcite $\left[\mathrm{CaCO}_{3}\right](\diamond)$, Diaspore $[\mathrm{AlO}(\mathrm{OH})](\square)$, Dolomite $\left[\mathrm{CaMg}\left(\mathrm{CO}_{3}\right)_{2}\right](\mathbf{\Delta})$, $\mathrm{Fe}(\mathrm{OH})_{3}(*)$, Gibbsite $\left[\mathrm{Al}(\mathrm{OH})_{3}\right](*)$, Goethite $[\mathrm{FeOOH}](\mathrm{O})$, Hematite $\left[\mathrm{Fe}_{2} \mathrm{O}_{3}\right](+)$, Hydrotalcite $\left[\mathrm{Mg}_{4} \mathrm{Al}_{2} \mathrm{O}_{7} .2 \mathrm{H}_{2} \mathrm{O}\right](-), \mathrm{Ca}_{3}\left(\mathrm{AsO}_{4}\right)_{2} .3 \mathrm{H}_{2} \mathrm{O}(\mathrm{O}), \mathrm{Ca}_{4}(\mathrm{OH})_{2}\left(\mathrm{AsO}_{4}\right)_{2} \cdot 4 \mathrm{H}_{2} \mathrm{O}$ $(\diamond), \mathrm{Ca}_{5}\left(\mathrm{AsO}_{4}\right)_{3} \mathrm{OH}(\square)$ and $\mathrm{CaHAsO}_{4} \cdot \mathrm{H}_{2} \mathrm{O}(\Delta)$ 
FIGURE 15 Saturation indices of $\mathrm{Fe}$ and $\mathrm{Al}$ oxides, carbonates, clay minerals and calcium arsenate with time at a depth of $1.5 \mathrm{~m}$ for cases 1(a), 2(b), 3(c) and 4(d); Calcite $\left[\mathrm{CaCO}_{3}\right](\diamond)$, Diaspore[AlO $\left.(\mathrm{OH})\right](\square)$, Dolomite $\left[\mathrm{CaMg}\left(\mathrm{CO}_{3}\right)_{2}\right](\Delta)$, $\mathrm{Fe}(\mathrm{OH})_{3}(*)$, Gibbsite $\left[\mathrm{Al}(\mathrm{OH})_{3}\right](*)$, Goethite $[\mathrm{FeOOH}]()$, Hematite $\left[\mathrm{Fe}_{2} \mathrm{O}_{3}\right](*)$, Hydrotalcite $\left[\mathrm{Mg}_{4} \mathrm{Al}_{2} \mathrm{O}_{7} \cdot 2 \mathrm{H}_{2} \mathrm{O}\right](-), \mathrm{Ca}_{3}\left(\mathrm{AsO}_{4}\right)_{2} \cdot 3 \mathrm{H}_{2} \mathrm{O}(\mathrm{O}), \mathrm{Ca}_{4}(\mathrm{OH})_{2}\left(\mathrm{AsO}_{4}\right)_{2} \cdot 4 \mathrm{H}_{2} \mathrm{O}$ $(\diamond), \mathrm{Ca}_{5}\left(\mathrm{AsO}_{4}\right)_{3} \mathrm{OH}(\square)$ and $\mathrm{CaHAsO}_{4} \cdot \mathrm{H}_{2} \mathrm{O}(\Delta)$

FIGURE 16 Variation of As concentration as a function of $\mathrm{pH}$ 


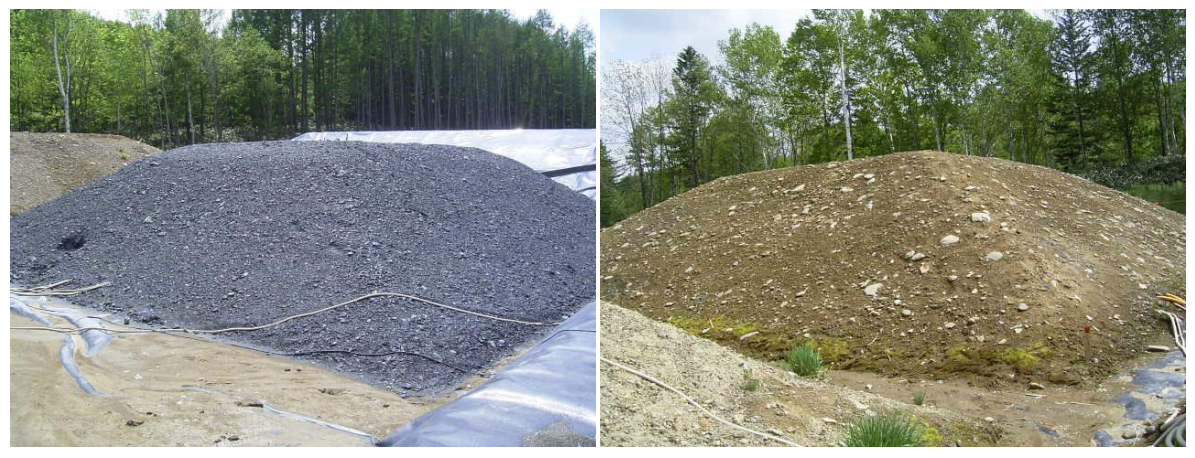

(a)

(b)

Figure 1

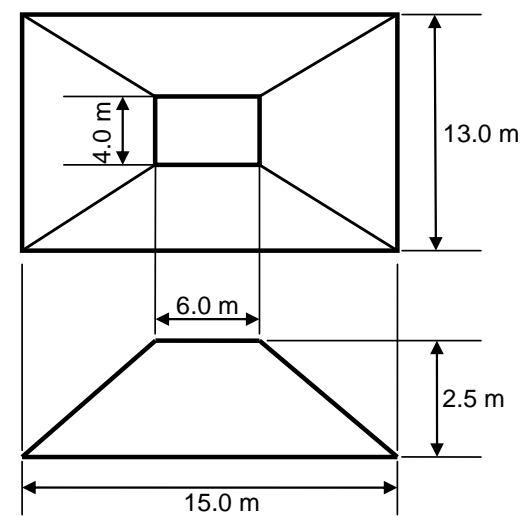

(a)

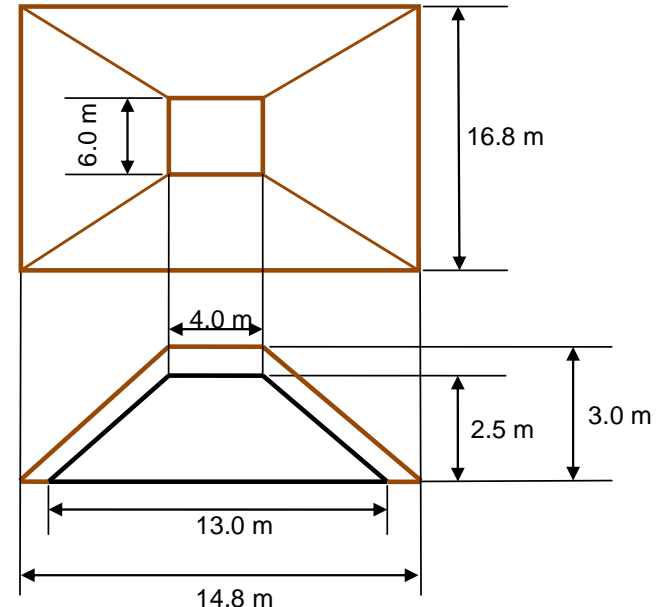

(b)

Figure 2 


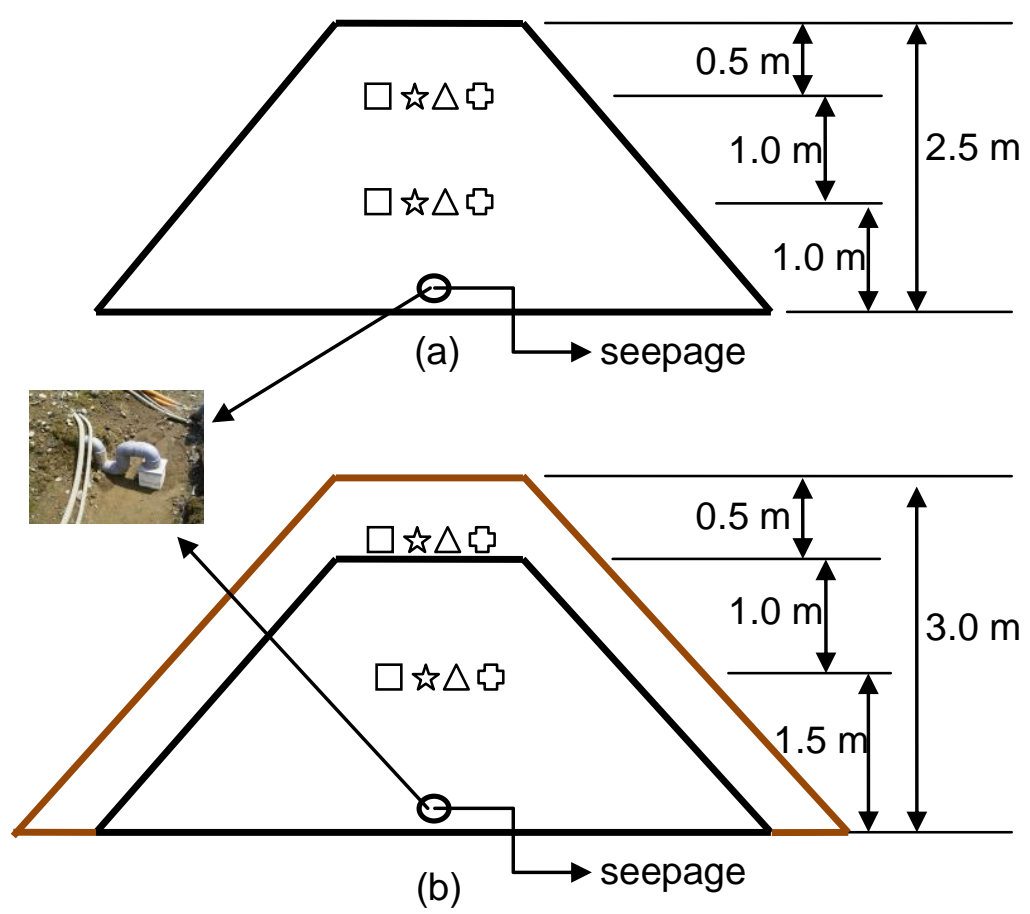

Figure 3

(a)

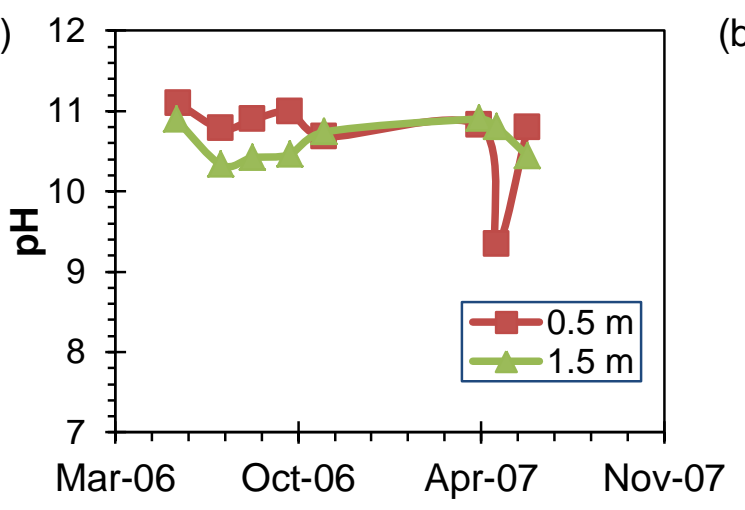

(c)

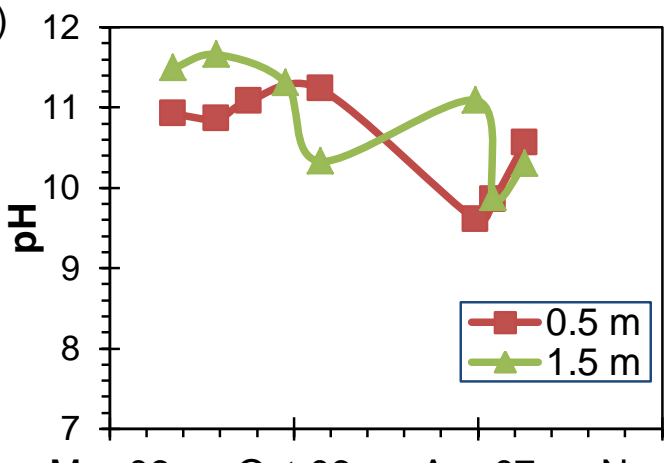

(b)

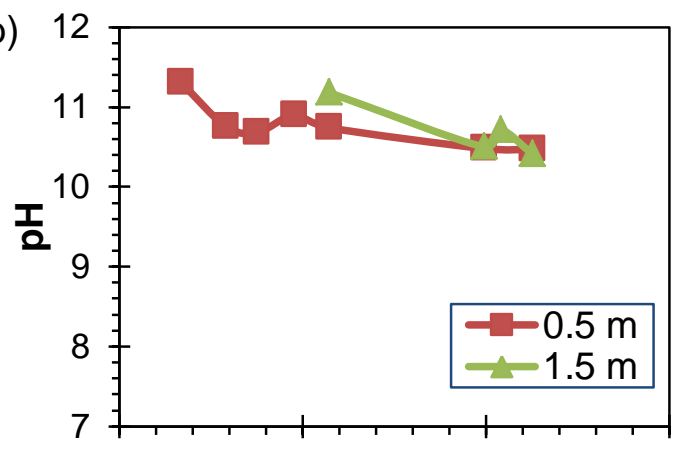

(d)

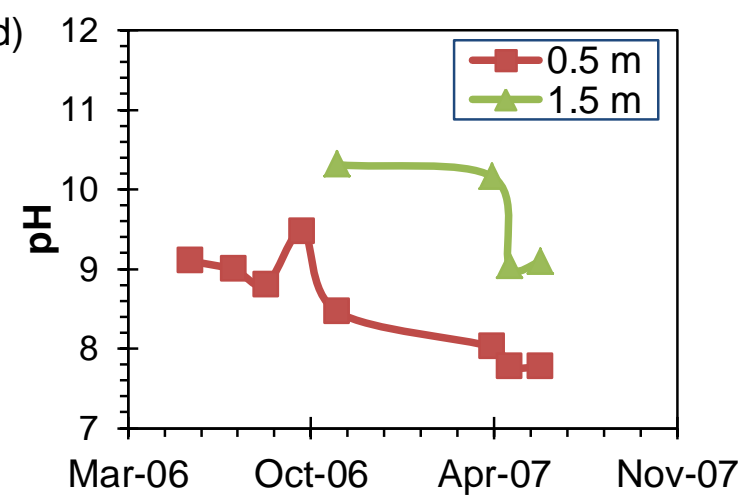

Figure 4. 

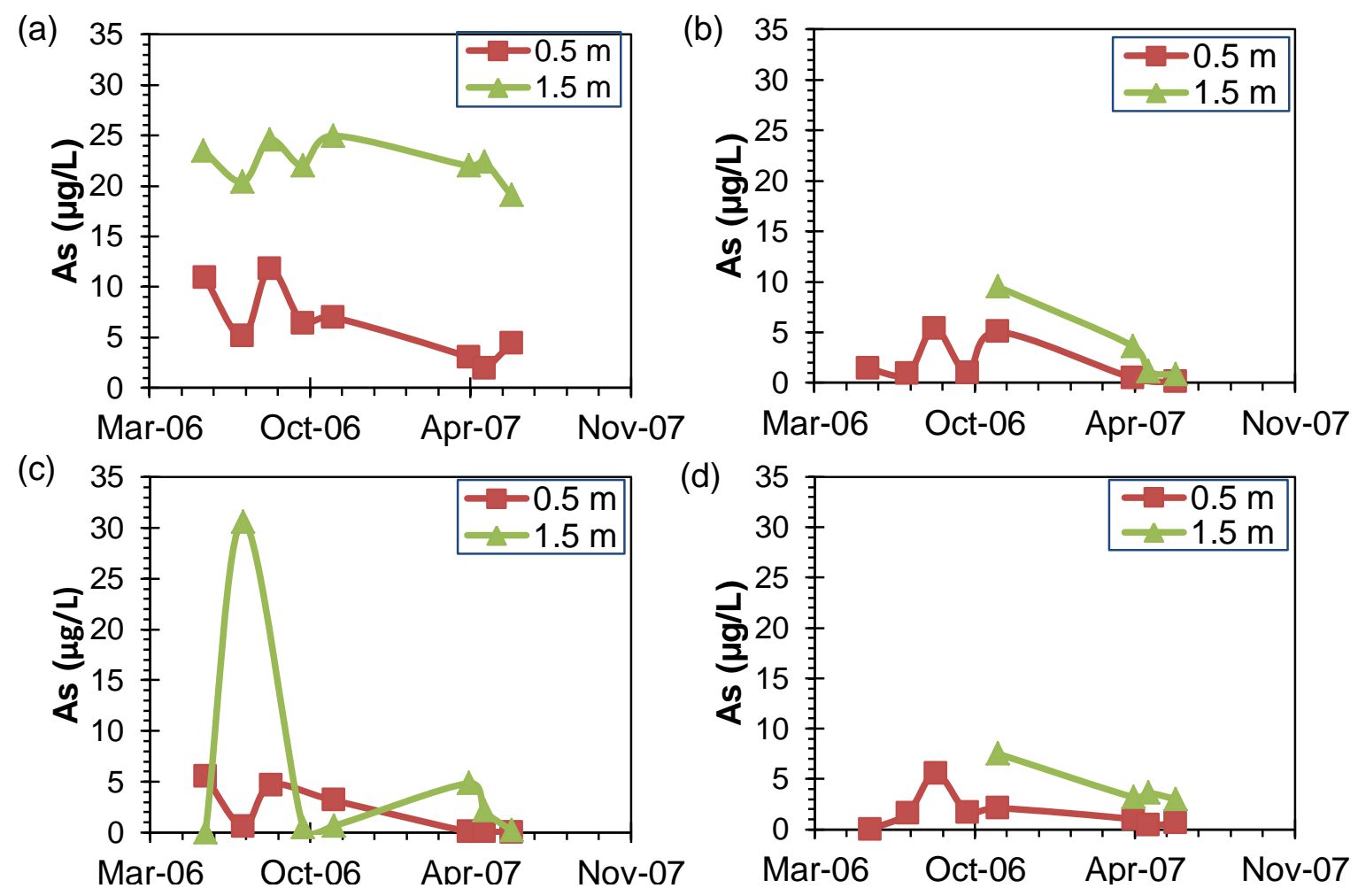

Figure 5 

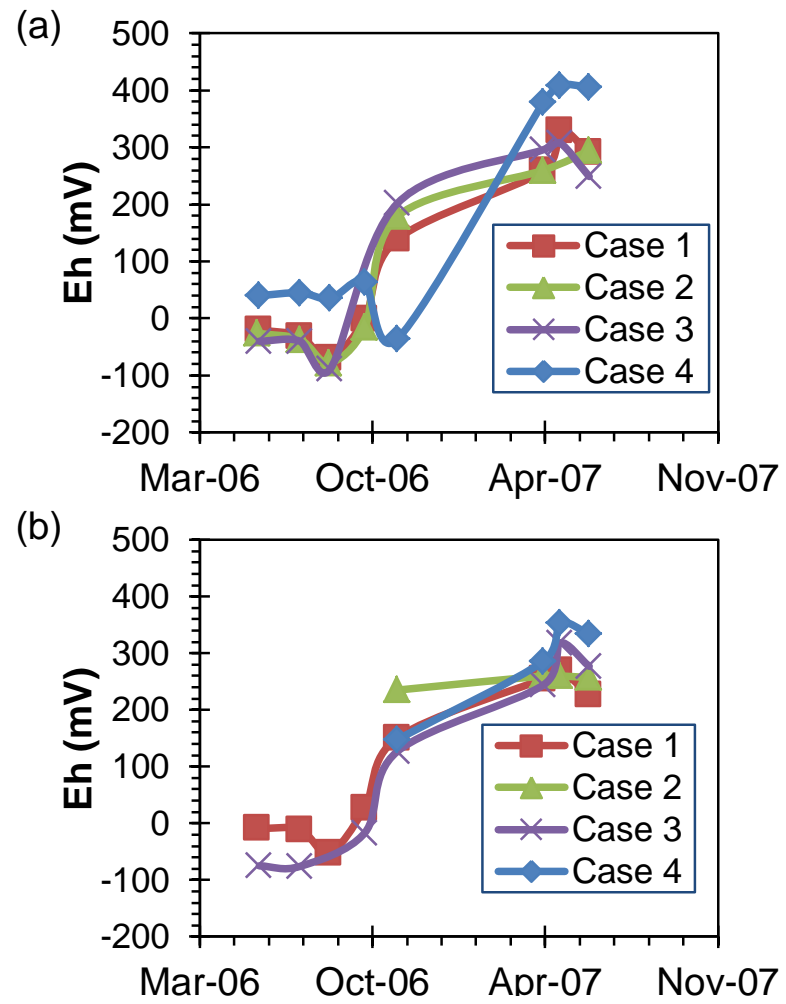

Figure 6 

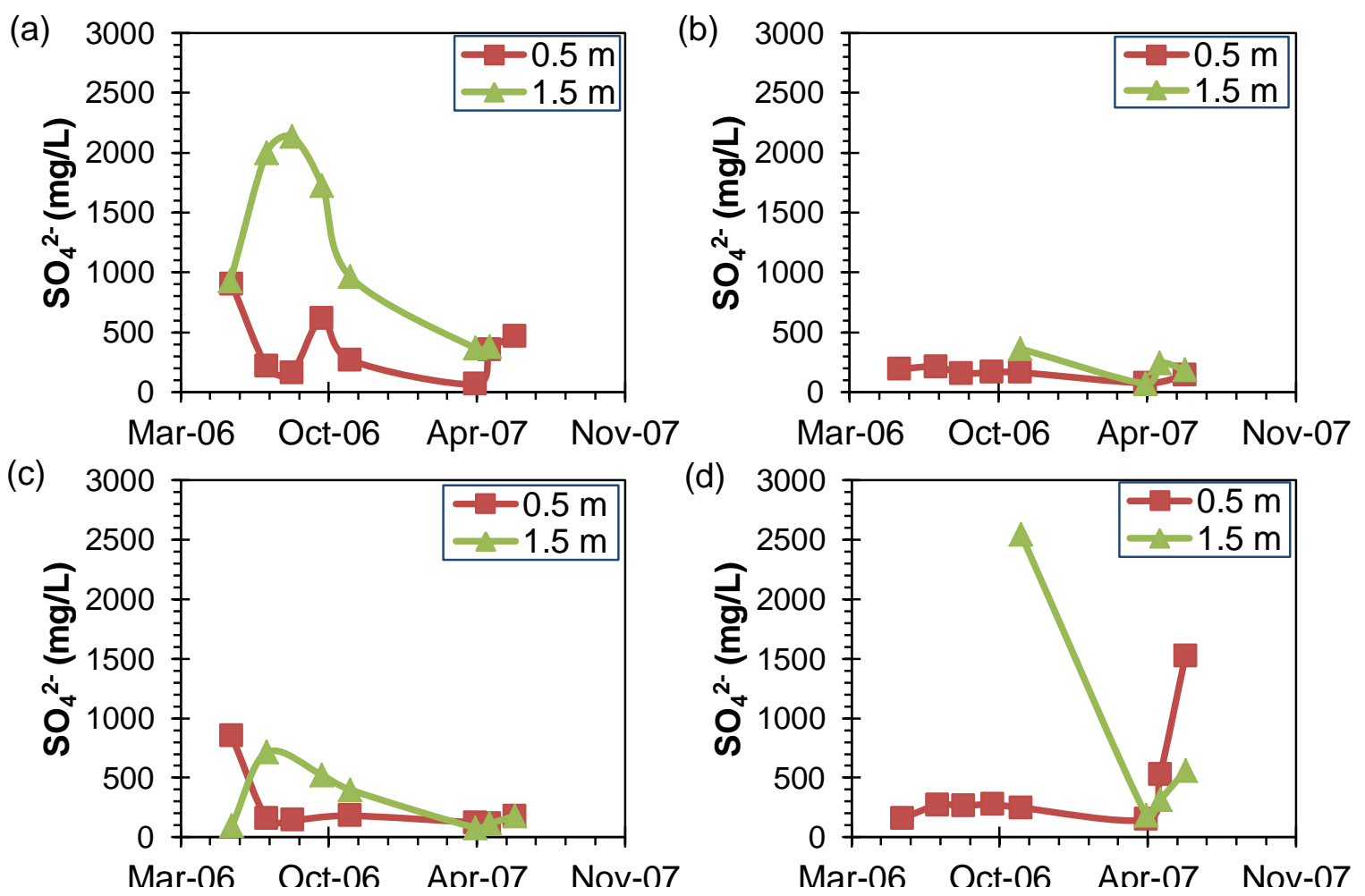

Figure 7

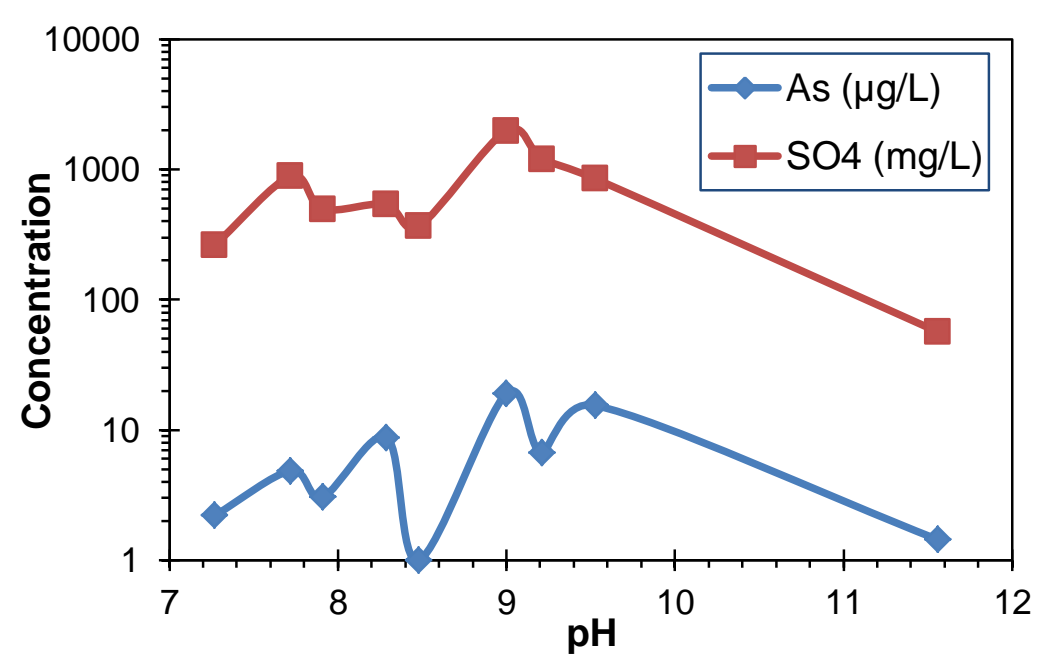

Figure 8 


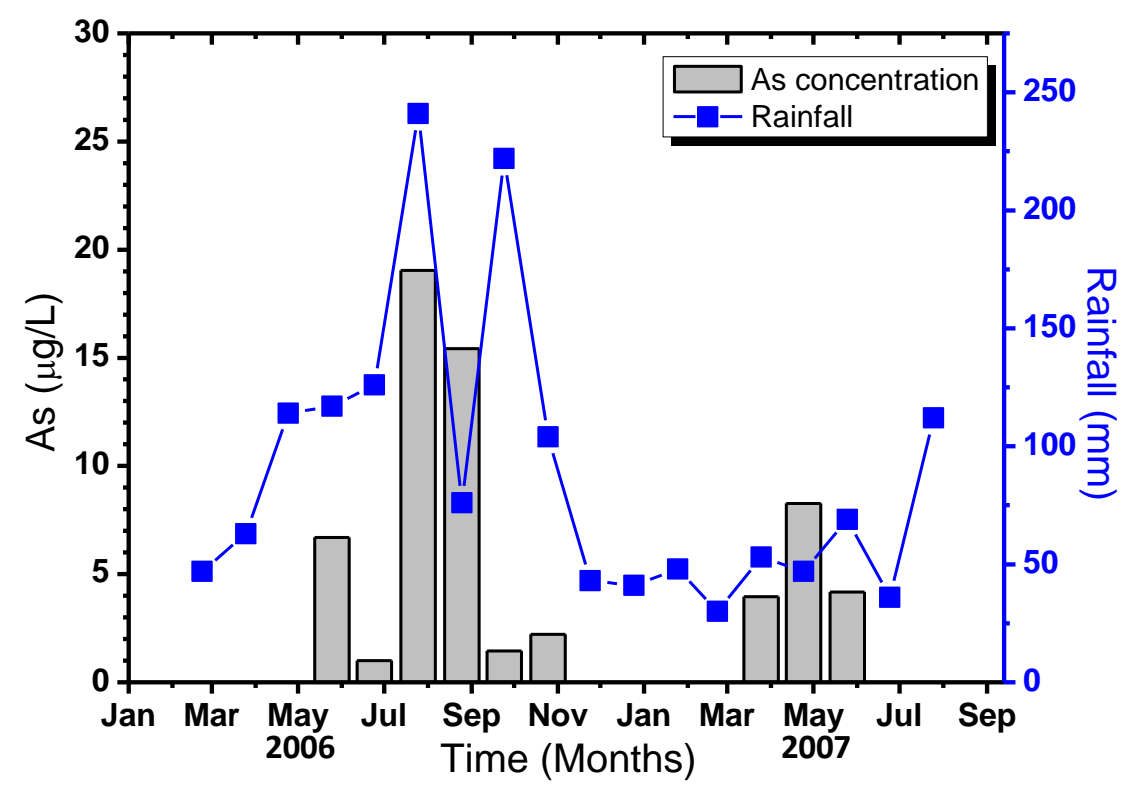

Figure 9
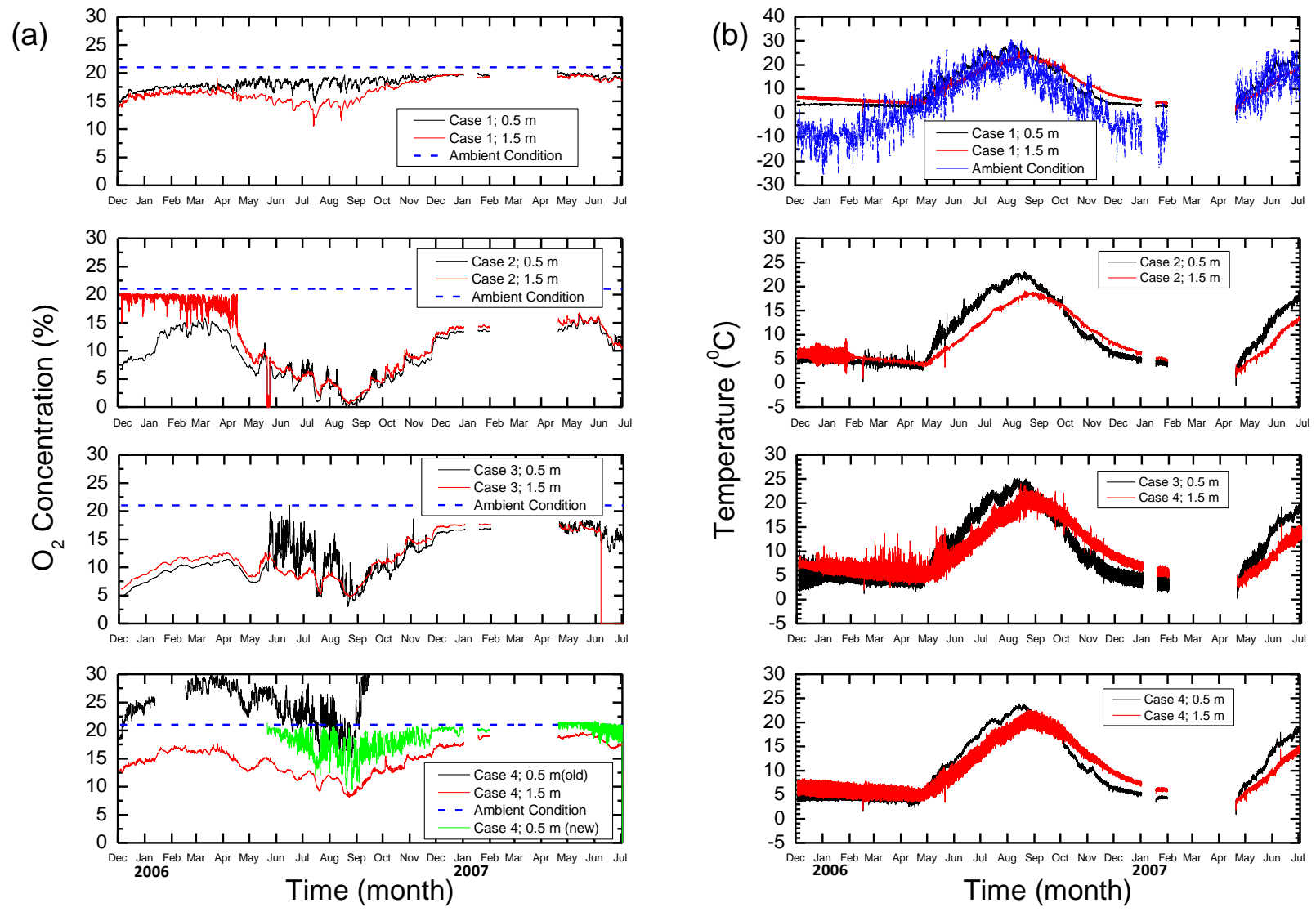

Figure 10 


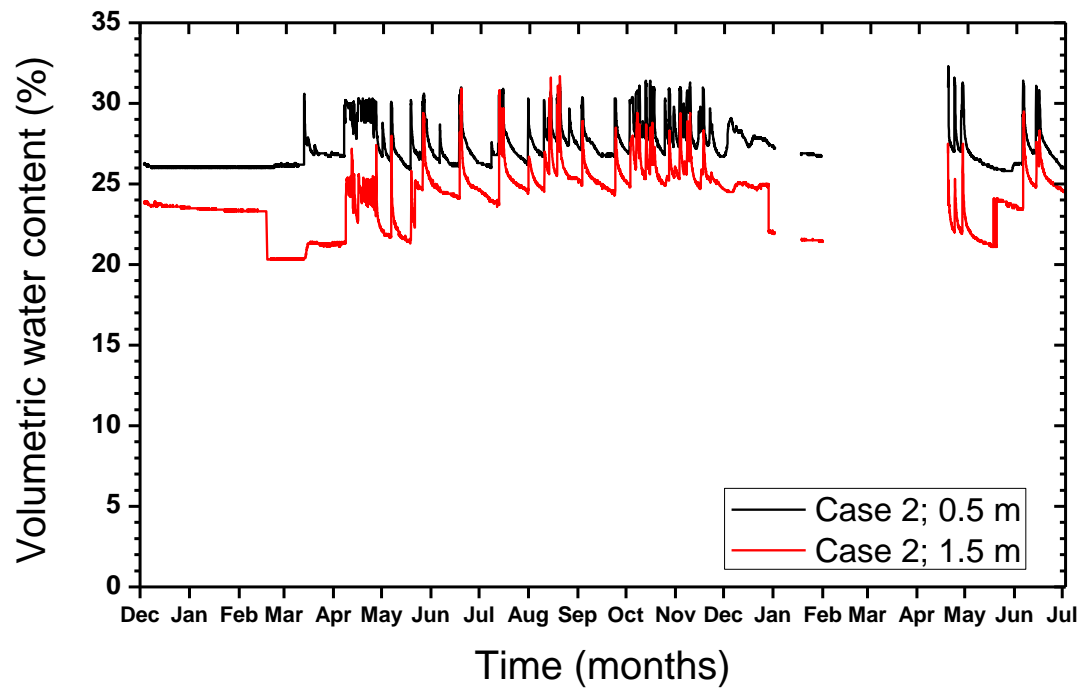

Figure 11
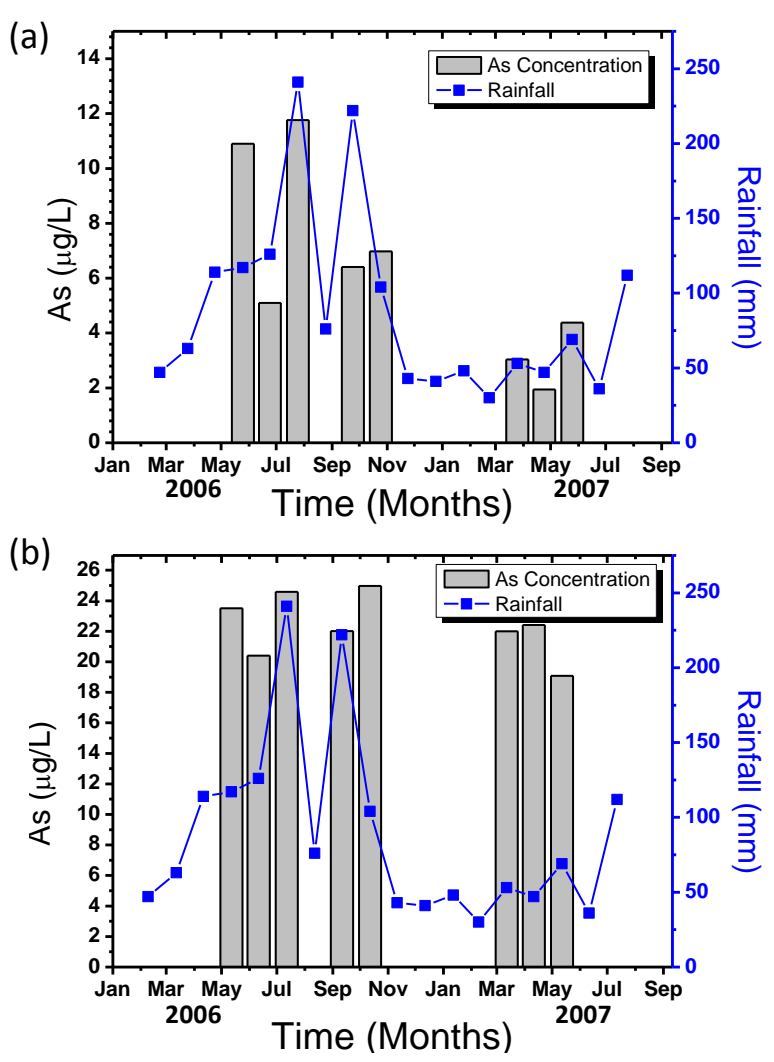

Figure 12 


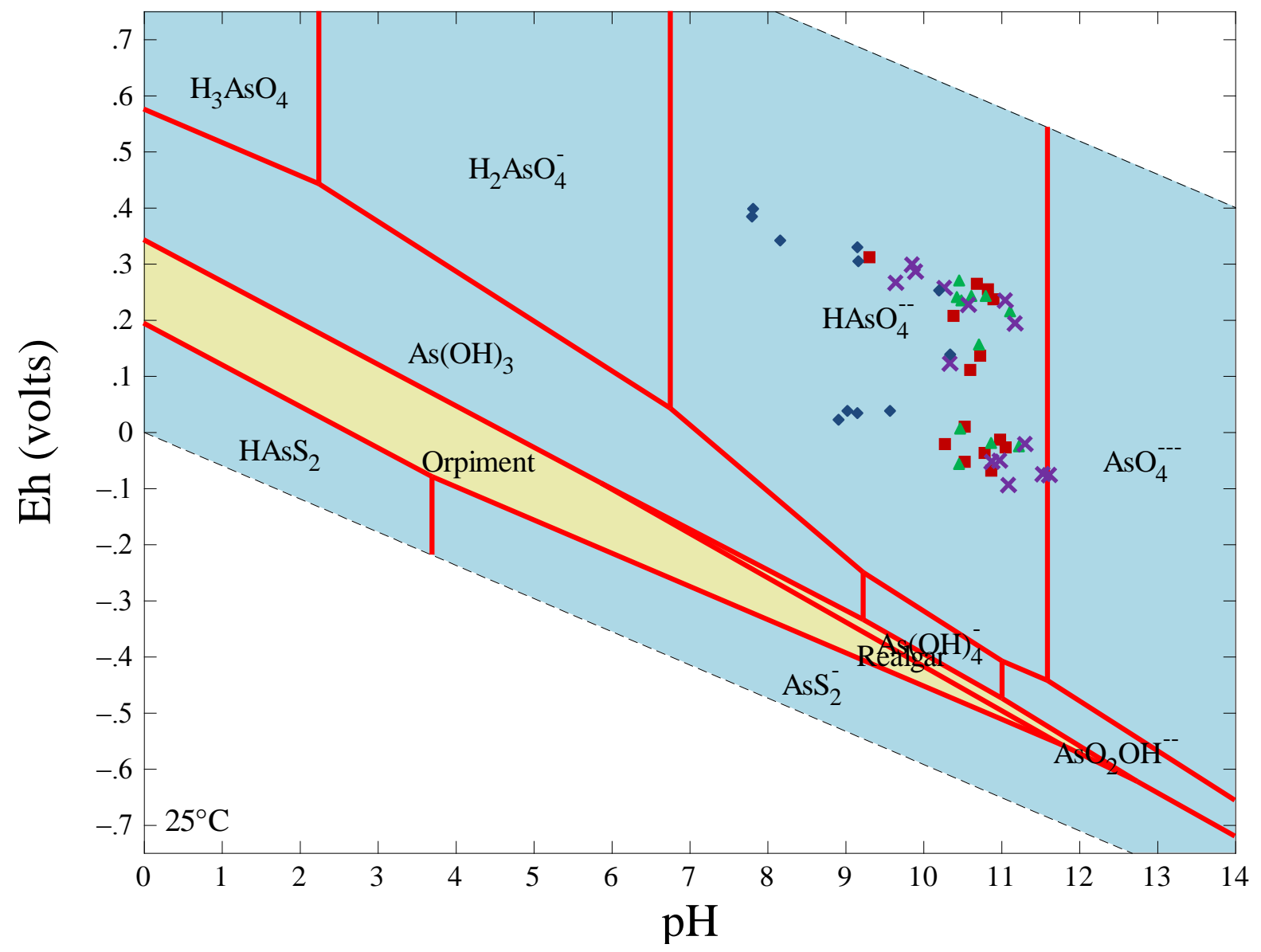

Figure 13 

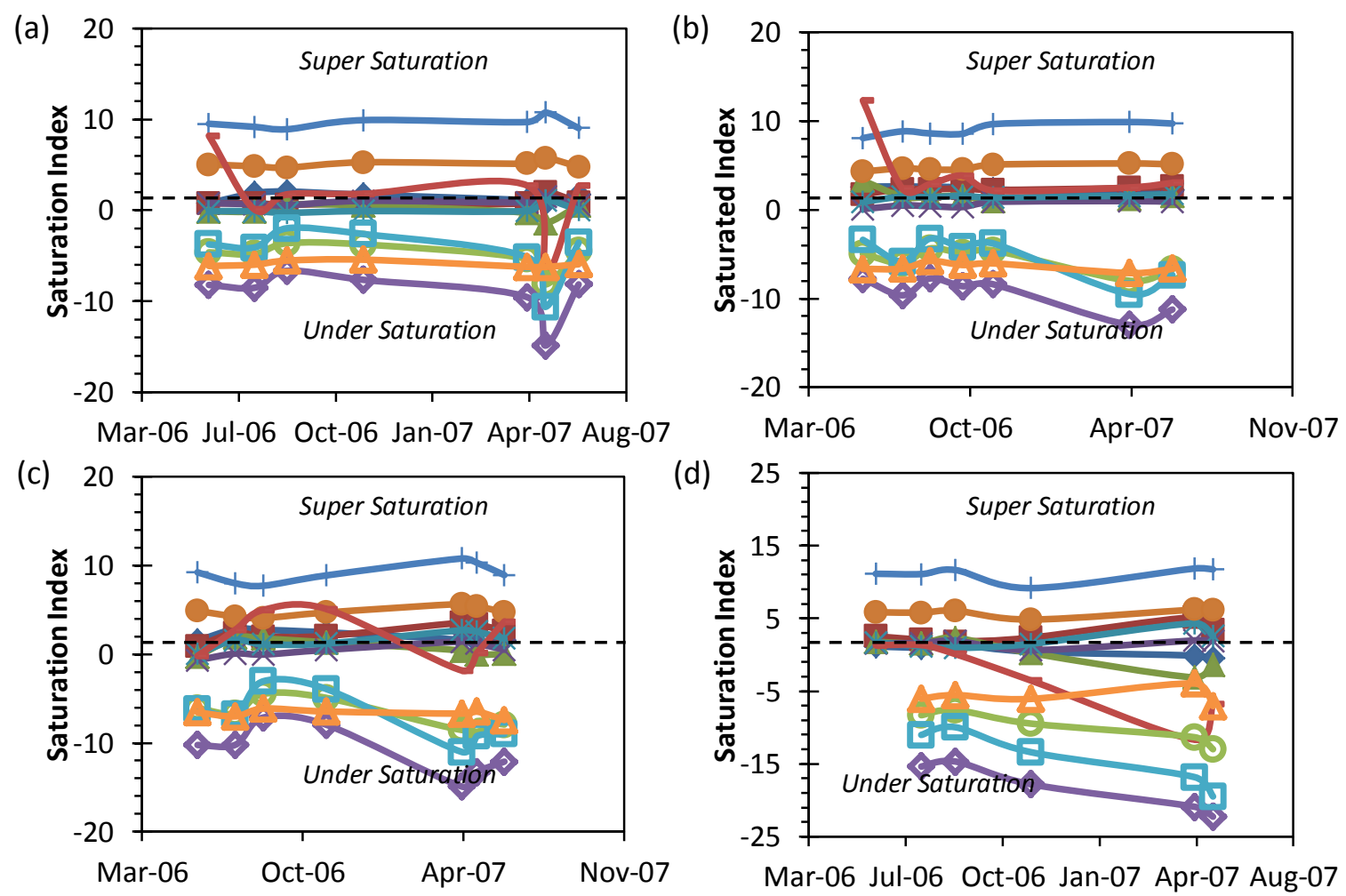

Figure 14 

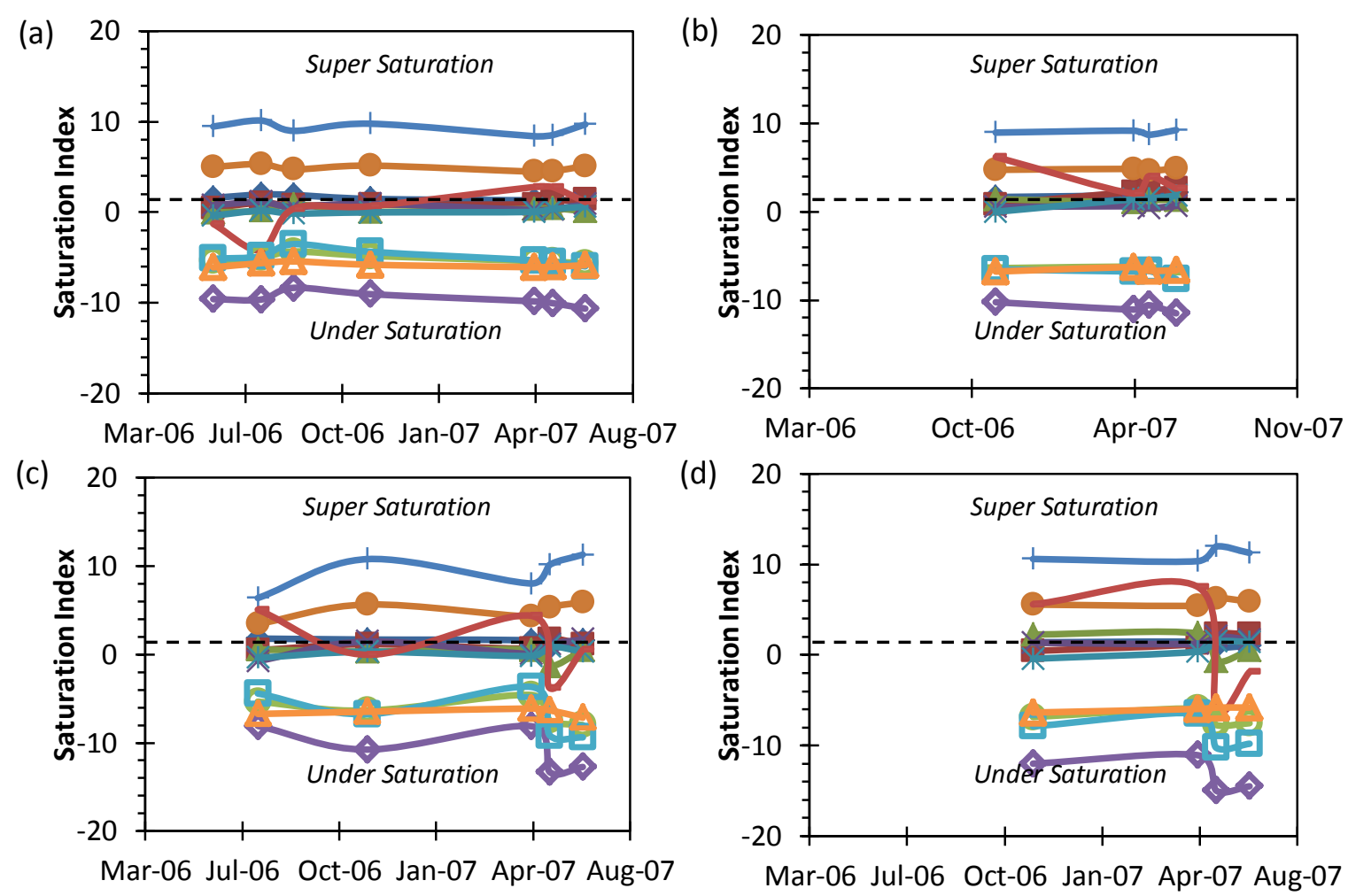

Figure 15

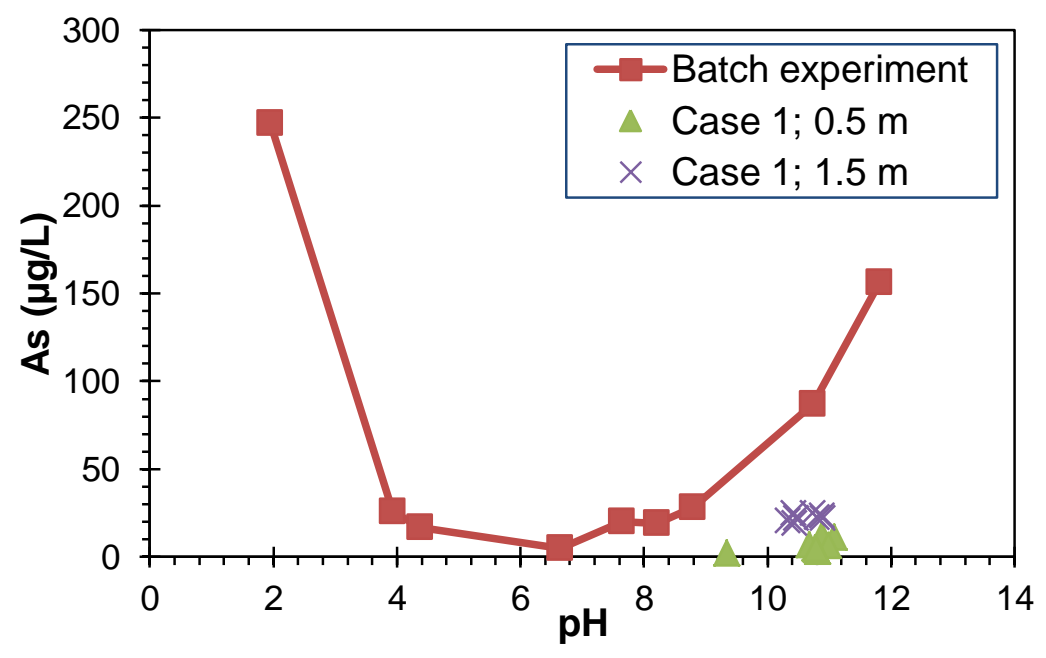

Figure 16 
Table 1. Chemical composition of the rock

\begin{tabular}{|c|c|}
\hline Chemical name & Amount \\
\hline $\mathrm{SiO}_{2}(\mathrm{wt} \%)$ & 43.0 \\
\hline $\mathrm{TiO}_{2}(\mathrm{wt} \%)$ & 0.41 \\
\hline $\mathrm{Al}_{2} \mathrm{O}_{3}(\mathrm{wt} \%)$ & 12.1 \\
\hline $\mathrm{Fe}_{2} \mathrm{O}_{3}(\mathrm{wt} \%)$ & 5.43 \\
\hline $\mathrm{MnO}(\mathrm{wt} \%)$ & 0.10 \\
\hline $\mathrm{MgO}(\mathrm{wt} \%)$ & 2.85 \\
\hline $\mathrm{CaO}(\mathrm{wt} \%)$ & 1.59 \\
\hline $\mathrm{Na}_{2} \mathrm{O}(\mathrm{wt} \%)$ & 0.50 \\
\hline $\mathrm{K}_{2} \mathrm{O}(\mathrm{wt} \%)$ & 3.02 \\
\hline $\mathrm{P}_{2} \mathrm{O}_{5}(\mathrm{wt} \%)$ & 0.04 \\
\hline $\mathrm{S}(\mathrm{wt} \%)$ & 0.27 \\
\hline As $(\mathrm{mg} / \mathrm{kg})$ & 10.5 \\
\hline
\end{tabular}

Table 2. Mineral constituents of the bulk rock

\begin{tabular}{ll}
\hline \hline Sample & Mineral name \\
\hline \hline & $\begin{array}{l}\text { quartz, feldspar, } \\
\text { calcite, muscovite, } \\
\text { rock (slate) } \\
\text { chlorite and } \\
\text { kaolinite }\end{array}$ \\
\hline \hline
\end{tabular}

Table 3. Mineral constituents of some boring core samples containing pyrite

\begin{tabular}{ll}
\hline \hline Sample & Mineral name \\
\hline \hline H10B-2 [22.2-22.6 m] & quartz, mica, chlorite, siderite and pyrite \\
H12B-1 [26.0 $-26.4 \mathrm{~m}]$ & quartz, feldspar, mica, chlorite and pyrite \\
(Silicified Rock) & \\
H12B-1 [53.5 $-54 \mathrm{~m}]$ & quartz, feldspar, mica, pyrite and marcasite \\
(Silicified Rock) & \\
\hline \hline
\end{tabular}


Table 4. Physical properties of covering soil and waste rock in each impoundment

\begin{tabular}{|c|c|c|c|c|}
\hline & Case 1 & Case 2 & Case 3 & Case 4 \\
\hline Type of soil cover & - & silty soil 1 & silty soil 2 & $\begin{array}{l}\text { silty soil } 2+ \\
3 \% \text { wood chips }\end{array}$ \\
\hline Dry density of waste rock $\left(\mathrm{g} / \mathrm{cm}^{3}\right)$ & 1.99 & 1.99 & 1.99 & 1.99 \\
\hline Dry density of soil cover $\left(\mathrm{g} / \mathrm{cm}^{3}\right)$ & - & 1.19 & 1.52 & 1.44 \\
\hline $\begin{array}{l}\text { Hydraulic conductivity of waste } \\
\text { rock }(\mathrm{cm} / \mathrm{s})\end{array}$ & $3.22 \times 10^{-2}$ & $3.22 \times 10^{-2}$ & $3.22 \times 10^{-2}$ & $3.22 \times 10^{-2}$ \\
\hline $\begin{array}{l}\text { Hydraulic conductivity of covering } \\
\text { soil }(\mathrm{cm} / \mathrm{s})\end{array}$ & - & $2.11 \times 10^{-4}$ & $9.06 \times 10^{-4}$ & $7.63 \times 10^{-4}$ \\
\hline
\end{tabular}

